Copyright (C) 2019 by Academic Publishing House Researcher

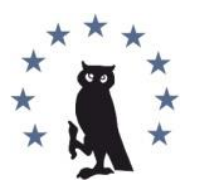

Published in the Russian Federation

European Researcher. Series A

Has been issued since 2010.

E-ISSN 2224-0136

2019, 10(4): 223-229

DOI: $10.13187 /$ er.2019.4.223

www.erjournal.ru

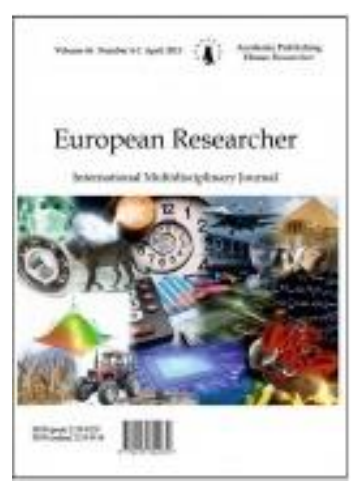

\title{
Peacekeeping and Social Conflict in Somalia: the Case of Amisom-African Union Mission in Somalia*
}

\author{
Abdishakur Jama a, Filiz Katman a, * \\ ${ }^{a}$ Istanbul Aydin University, Istanbul, Turkey
}

\begin{abstract}
This paper aims to explain the causes of the social conflict in Somalia and highlighted the factors contributing to the instability. The study also analysis the different peacekeeping missions in Somalia focusing on the various phases of peacekeeping operations. Although, special consideration is given to the challenges facing African union's mission in Somalia (AMISOM). The country has been playground for different political actors, each one of them tries to maintain and engage the conflict of the country one way or the other with varying interests. The study explains social-conflict theories to give understandable picture of what actually went wrong in Somalia. furthermore, the impact of external actors on peace and stability are discussed. Achieving stability in Somalia is not an easy task, therefore, requires both domestic and international efforts to easy the situation and bring sustainable peace in the country.
\end{abstract}

Keywords: Al-Shabaab AMISOM, AU, Peacekeeping, Social-Conflict, UN.

\section{Introduction}

Somalia is located in the Horn of Africa. The country is regarded as very poor state though Somalia is a rich country in terms of natural resources. Somalis are homogeneous united by culture, language as well as religion these commonalities are rare in most cases (Elmi, 2010). Colonial powers divided the Somaliland into five major parts. Italian Somaliland together with British Somaliland became the independent Somali Republic in 1960 (Abdullahi, 1992). Although, Djibouti which was French Somaliland later got its independence in 1977, other two the Northern Frontier District (NFDs) and finally, the fifth division Ogaden region are still under the role of Kenya and Ethiopia respectively. Therefore, the five parts are represented in the five-pointed star which is on the national flag adopted by the Somali Republic while gaining independence in 1960 (Lewis, 1993).

After the fall of the central government in 1991 Somalia experienced one of the most damaging civil wars in Africa. The collapse of Siyad Barre regime left a political vacuum whereby the clans, sub-clans, warlords, and even Islamist groups took the stage and struggled for power and resources resulting endless conflict. This caused a hostile situation where everyone claimed legitimacy. Opposition forces were not ready to take over and maintain law and order. They failed to establish government institutions or in other word restore state institutions.

*This article is based on the dissertation of the author entitled Abdishakur Jama, Peacekeeping and Social Conflict in Somalia: The case of AMISOM-African Union Mission in Somalia

${ }^{*}$ Corresponding author

E-mail addresses: filizkatman@aydin.edu.tr (F. Katman), cjamacnur@gmail.com (A. Jama) 


\section{Discussion \\ Peacekeeping}

Peacekeeping consists of coordinated existence of military and civilian personnel, sometimes with police tasked for various duties like humanitarian help, protecting human rights, policing, observation of the electoral process and monitoring as well as economic and social restoration and reestablishment (Annan, 1997). Whenever peacekeeping is mentioned, what comes to the mind is that the United Nations peacekeeping can be either traditional or multidimensional missions. Peacekeeping therefore attempts to limit or reduce the scale of the conflict. Peacekeeping has always been something tied to the United Nations but there are rising debates about which peacekeeping suits best regarding violent conflict and what strategy should be employed in order to address the political will of it.

The United Nations Security Council (UNSC) is an organ responsible to solve disputes among nations via peaceful methods like negotiation, mediation and conciliation. The fundamental purpose of the United Nations is to safeguard peaceful relations between states. The organization require military force to tackle such problems arising from the international arena. Therefore, the objective however is that UN should deploy forces where necessary.

\section{Social Conflict Theories}

Class theory of conflict explains the fact that every society has its classes and the relationship between them when it comes to their mode of production. According to famous Marxist theory all conflicts emerge from class related struggles whether that may the ambition to own the means of production although, the capitalist would do whatever it takes to hold their place as the top class of the society (production means owners). The capitalist controlling the means of production may have an influence of the life of the working class this sometimes causes disputes between the two. What causes the conflict is the decisions made by the capitalists regarding distribution and allocation of resources and sometimes wages. As result, the working class may see themselves as the victims which causes conflict. Nonetheless, what is vital is that the outbreak of a conflict needs conditions to be fulfilled. That may be the ability to know the exploitation and also the organisation to form movements or political parties capable of practicing class struggle (Goldstone, 2014). To Somalia context much is not written from class struggle as triggers of conflict but, some recent studies claim the presence of conflicts related class struggle in some places. For example, Alex de Waal argues state influence on both agriculture and pastoralism and the fact that state controlled almost all of the production modes resulted some kind of capital accumulation (De Waal, 1996). Indeed, most of the production modes were controlled by either the state or particular group of people who had good ties with state in1980s. Most importantly, the country was under the leadership of socialist leader Siyyad Barre who embraced socialism in 1970 .

Primordial theory also puts emphasis on primordial groups like racial groups, clans and subclans. Clan is something that slowly forms identity which can also be inborn or via psychological procedures in which politics and societies have small effect. This theory best suits Somali state case where clan is important. Moreover, Somalia is a nation of clans, almost most of the conflicts which occur in Somalia are clan-based conflicts where people are categorized based on their clan lineage. According to the theory the authors exquisitely demonstrated how hegemonic pattern of relations persists most of the postcolonial nation states and there is no exception to Somalia whereby few members of the society control and dominate the power. In fact, particular clans in Somalia dominate political stage of the country which is based clan system. As result elites from other clans establish rebel groups. In short those belonging to marginalized groups "civil" or "military" create insurgencies to get what they want causing conflict erupt in the society (Klay, Kieh, 2002). On the other hand, World Bank stated in a report "almost all conflicts in recent Somali History fall under clan-based conflicts". Clan is something that be used in both good and bad ways. It can be used as a tool for solving problems or it can be used as something which a specific clan group pursue its political goals and resource control.

The Electric Theory of conflict explains that one factor is impossible to explain the difficulty of internal conflicts or in other word civil wars. The theory further explains that conflict is result of several variables that may be historical, political, economic social and so many others. Hence, several coordinated factors can cause conflict. For instant, mis-treatment of humans or human rights abuses, mis-use of political power, poverty, suppression all these factors may trigger conflict. 
To find solution for a conflict requires different methods to be implemented to play role. For example, conflicts sometimes require peacekeepers to intervene the situation like it is true in the case of Somalia where peacekeeping forces are currently present. Non-use of force can also be an option for instance negotiation and mediation.

\section{The Impact of the Cold War}

There has been a competition between super powers over the control of Somalia since the country took its independence in 1960. The rivalry between the great power like USSR and US resulted many changes which have taken place in the region. Although, the Soviet Union won the heart of Somalis when the two reached agreement and signed a military agreement worth of 30 million US in 1963 (Chirumamilla, 2011: 189).

The impact of the war together with refusal of foreign aid were major factors which caused the Somali central state to fall. Moreover, withdrawal of foreign assistance was area of focus for many scholars as a major factor of state collapse including, Ahmed Samatar, Ken Menkhaus, Walter S. Clarke, Robert Gosende, John Prendergast and Terrence Lyons. For example, Terrence Lyons links the Somali state collapse with the removal of foreign help/assistance and strengthened domestic call for better political goods. He argues that Somali state collapsed when "absence of foreign aid and increased need for good governance and economic enhancement." (Lyons, Samatar, 1995) Walter S. Clarke and Robert Gosende (Clarke, Gosende 2000: 129-158) are in line with Terrence Lyons of the negative impact of withdrawal of foreign aids/assistance but, partially. They argued that "Somalia's downfall may not be solely due to cold war but, there are also other factors contributed the state to fail". Though, Ahmed Samatar regards the collapse combination of three things and he wrote "due to devastating and humiliation from the defeat, declining economy and lack of superpower support, Somali's political situation turned upside-down. All eyes were on the regime and the loss from the war overwhelmingly changed everything causing a situation characterized of suspension and bitterness" (Samatar, 1994). Ken Menkhaus argues that foreign assistance was vital to Somalia economy. He went even further to note "it was obvious that the external assistance was vital for the Somali economy and it is also clear that local state resources were not enough. Even observers in 1950 os were concerned that and independent Somali state would not be economically feasible" (Menkhaus, 1997, p. 126) furthermore, Ken Menkhaus and John Pendergast went even further more, seemingly over expressing the significance of the foreign aid. They argued, "Somalia entirely depended on the foreign aid especially in cold war era and when the war ended the country's government collapsed. The central state's authority depended on the foreign aid the country collapsed soon after the aid was frozen in late 1980s" (Menkhaus, Prendergast, 1995).

\section{Somalia-Ethiopia War}

Somali Irredentism is in fact based on the history that the Somali Speaking area in the Horn of Africa are divided and occupied among four colonial powers during the partition of Africa. The Colonizers were Britain, Italy, France and Ethiopia. Somali nationalists encouraged by the Bevin Plan, desired the concept of "Greater Somalia", established on the idea of re-uniting all Somali Speaking people living in five separate regions as represented by the Somali Flag's fivepointed white star. Two of the five regions, the British Somaliland and the Italian Somaliland united and became in 1960 the Somali Republic. The other three remaining regions including the current Republic of Djibouti, Ogaden or Somali-region in Ethiopia, and the NFD (Northern Frontier District) in Kenya. Chasing the vision of "Greater Somalia", the newly born State of Somalia was Manipulated, encouraged into the cold war by the major powers namely the US and Soviet Union competing for the influence of the strategic Horn of Africa where Somalia locates (Fishel, 1997). After Military aid from the soviets Somalia went war with the Ethiopia this created hostile environment with the neighbouring countries affecting the peace and the stability of the region. Somalia fought two wars with Ethiopia in 1964 and 1977-8 (Somalia-Ethiopia war) the later, however, was internationalized and devastating not only it was one of the reasons why Somalia is not at peace today but, it also had an impact on peace of Horn of Africa as a region (Nkaisserry, 1997).

\section{Primordial Political Culture}

Somalia is a nation of clans in search of a state, in fact clan is something that can be used good or bad in nation building. It can also be used as a tool for solving issues rising inside the society in short it can also be a tool for a peace or conflict resolution method. When we look at the 
developed world the things which hold the most important for the traditional societies such as cultural traits and religious beliefs become less important in the modernized world. Modernization theory holds this argument which also the Somali Youth League (SYL) agreed to have this concept while denying the clan attachments by its members. The Somali Youth league focused the importance of the unity encouraged its members that being Somali is above everything else though later clan was used to gain political goals because of the existing political parties. Many attempts were made to tackle the devastating challenge of clannism. Clannism can cause many problems to the Somali Society however; nothing had changed and later Somalis fought wars based on clan (Abdullahi, 2016).

\section{The role of State and Non-state Actors in Somalia}

Ethiopia's Military Intervention

When we go back to history the relation between Ethiopia and Somalia is characterized turbulent one. Somalia and Ethiopia are opposite from almost everything the two have different ethnic and religious backgrounds. According to Somali people's view, Ethiopia is one of the former colonial powers that divided Somali land into five parts. In fact, King Menelik of Ethiopia participated the famous conference for partition of Africa. As result, in 1954 Ethiopian was given the Ogaden region of Somalia by the British government. Consequently, Ethiopia and Somalia fought two wars in 1964 and 1977. The cause of the war was Ogaden region which originally belongs to Somalia even the habitants of this region are Somalis but controlled by Ethiopian government. Somalia hosted and supported opposition leaders to fight Ethiopia. On the other hand, Ethiopia regime also supported Somali rebel groups SSDF, SNM and other groups.

In 2006, Ethiopian government intervened Somalia with its own political goals and military support from US. Ethiopian National Defense Force entered the Sovereign Somali land to help the Transitional Federal Government. Even though, the allied armies of ENDF and Somali National Force weakened the Islamic Courts Union, the violence lasted many more years causing considerable damage to the parties involved and even deteriorated the conditions of many Somali people in Southern part of the country (Albin-Lackey, 2008).

\section{Kenya, Djibouti, Sudan and Yemen}

When talking the influence of the neighbouring countries in the situation of Somalia, Ethiopia and Eritrea dominate the rest of the states. These states have been strongly involved in Somali disputes. On the other hand, Sudan, Djibouti, Kenya and Yemen are not as important as the previous two. For example, there is a good relationship between Somalia and Djibouti unlike Somalia and Ethiopia so there is nothing much to say between Djibouti and Somalia. However, one may argue the role Djibouti played is a significant one for hosting several conferences especially reconciliation conferences. In short Djibouti has tried to play a broker role for providing the platform for Somali peace talks most recent ones being the talks between the TFG and ARSA-A factions in August 2008 as well as state building initiatives. Sudan also played mediatory role in Somalia's crises and remained neutral the whole time.

Kenya is different than Sudan and Djibouti combined because is a country which share a border with Somalia. It was recently when the Kenyan government decided to send its troops in Somalia to be part of AMISOM. It can be said that Kenya hosted large number of Somali refugees in recent years though the country is still for Somali irredentism which makes her similar with the Ethiopian state. One can also say that Kenya took part of the regional and sub-regional efforts especially IGAD when talking the security situation in Somalia.

Yemen is also a county which played a minor role in Somalia's crises. Muthuma claims that there are enough evidences that some of small arms and light weapons (SWAT) which the waring parts in Somalia using come from Yemen but, there is no enough evidence whether the Yemeni state was engaged or not. In contrast, Muthuma emphasizes that some Arab regimes are directly or indirectly supporting some of the insurgent groups in Somalia. This may be because some Arab states see that the animosity between Somalia and Ethiopia rooted the fact that they believe in two opposing believes Somalia is leading the Islamic faith in the region while Ethiopia is also leading the Christianity faith in the Horn of Africa region.

African Union Mission in Somalia (AMISOM)

After Ethiopian military withdrawal that helped the transitional federal government to settle Mogadishu. In December 2006, AMISOM mission to Somalia installed. In fact, the mandate deployed the mission was given by African Union in January 2007. Soon as the mission started the 
United Nations especially the security council showed support towards the deployment of the peacekeeping forces (Murithi, 2007). AMISOM started the mission with 8000 soldiers mandated to safeguard transitional government staff and take part actions against the anti-government groups like Al-Shabaab. The operation also provided civil military missions and humanitarian support. Part of the AMISOM's mandate was to support the government of Somalia in terms of military capacity whether that may be training and mentoring the Somali police force for the best way possible. AMISOM continued its mission of supporting the transitional federal government while on the other hand, the Ethiopian troops were withdrawing from Mogadishu. In 2009 Ethiopian forces left Mogadishu and AMSIOM focused to protect special members of the TFG and key areas in Mogadishu including the presidential palace known as villa Somalia, the airport, and K4 junction connecting them. In December 2011, a new military strategy was developed. This expanded AMISOM's military personnel making the number 18, ooo. This new military strategy expanding the operation was facilitated by the AU's Peace and Security Council and UNSC in January and February 2012 The new offensive military campaign resulted the removal of Al-Shabaab from the capital city Mogadishu.

The Role of AU, IGAD, and the Arab League

The two most dominant organization in Somalia's situation are the African Union and the IGAD, their involvement in the country's crises is important to mention. OAU has recognized Somali National Government (TNG) later it was the AU which also recognized Somalia state as Transitional Federal Government (TFG). The role of the AU and IGAD combined is vital one compare to the Arab league which is a minor role. The Arab league has been trying to play a mediatory role in the security situation in Somalia. It was the AU who decided to send peacekeeping troops to Somalia in 2007 with the recommendation of the Peace and Security Council (PSC) to replace the Ethiopian army presence in the country. Uganda and Burundi were the first two countries which offered troops though AMISOM was expected to provide 8, ooo troops later that number got increased and Kenya and Ethiopia added troops to send Somalia as part of the AU mission.

It was in July 2012 when the AMISOM accepted the Kenyan troops to be integrated into AMISOM and be part of the peacekeeping operation, though there were suggestions that the neighbouring states cannot send peacekeeping forces to Somali soul meaning Kenya and Ethiopia. It is clear that the AU is always in cooperation with the Regional Economic Community (REC) especially IGAD in the mission of bringing peace keeping operation in Somalia. However, one may argue that IGAD has been partially playing the situation in Somalia because of Ethiopia's influence of the regional block. In short, Ethiopia has huge influence on IGAD's decisions.

\section{Challenges of African Union's Military Interventions}

Security Threats

Somalia has been struggling to establish civilian state because of many issues security is one of them. In 1960 the former British Somaliland and Italian Somaliland formed union creating the Somali republic. Since the establishment of the republic the countries security situations has been worsening leading to complete collapse in 1991. After the failure of the Somali state several attempts has been made to rebuild the state good example is the creation of a transitional government. Though, it faced enormous challenges from Islamist insurgency in spite of the Ethiopian help to intervene in December 2006. It is been argued that the Ethiopian Intervention and the defeat of the Islamic Court Unions (ICU) have resulted huge damage on the civilian peace in south central Somalia (Albin-Lackey, 2008). Moreover, the Darod-Hawiye rivalry, competition and the existence of resistance manoeuvres made security situation even more difficult to solve.

The first Transitional Federal Government led by President Abdullahi Yusuf failed to establish a broad-based government. It was ravaged by internal conflicts such as dis-agreements among different government organs most notably the confrontations with the prime minister. Although, the real security threat was coming from Al-Shabaab who did not accept the power sharing deal developed between Sheikh Sharif Sheikh Ahmed's alliance for Re-liberation of Somalia Djibouti division (ARS-D) and TFG Prime Minister Nur Hassan. The talks between Transitional Federal Government and the moderate Islamist group led by Sheikh Sharif was held in Djibouti, Al-Shabaab on the other hand, had already separated from the moderate Islamist group refused the peace deal and waged war against the TFG. In 2011, collective military mission between multinational forces and Somali military started (Heinlein, 2014). The operation was officially 
conducted by the Somali military with expected assistance from AU troops to help the TFG gain control more territories. On August the same year Transitional Federal Government forces with their AU troops succeeded to take over Mogadishu from Al-Shabaab. The next destination was Kismaayo which was the major source of income and the last Al-Shabaab stronghold, on 28 September 2012 the national forces helped by AU troops and Ras Kamboni militia began their raid towards Kismayo. The allied forces managed to re-capture much of the city form Al-Shabaab (Chonghaile, 2014).

\section{Lack of Exit Strategy}

It is not even clear that that there is guide to the exit which leads me my point that any given operation or mission has to have its timeline indicating the withdrawal and closure of the entire operation in a certain period of time. It is impossible for a mission to be assumed indefinitely in this modern time therefore, a mission should come up with timeline or strategy indicating the termination of its mandate and most importantly the handover of its responsibility to the domestic partner, to the government of Somalia. It is obvious that the local actors are not happy AMISOM's presence for longer period of time. Some already believed that this is similar to military occupation because of the lack of exit strategy. The exit strategy still remains unsolved equation when talking the peace-keeping operation in Somalia. In one way it was predicted that the operation will turn to be UN operation but, nothing had changed ever since. AMISOM is still persuing peacekeeping operation which has no timeline. Though, the situation is changing, the current Somali government is trying to build the national army which everntually will replace the AMISOM mission. The fact is that Somalia still lacks the capacity to take control of the contry and maintain law and order. There are rising debadets whether federal system will work since the country is divided into small state parts where each state claims autonomy. This will make everything difficult for the central state to reach it is desired goals.

\section{Conclusion}

The collapse and the failure of Somalia as a state can be simply explained as failure of postcolonial state and its elites which was built on fragile and shaky foundations. Unlike the most of the other African states, Somalia is a homogeneous nation-state and one of the early democracies in Africa. Because of the colonial legacies Somali people happen to be citizen of four different countries in the Horn of Africa: The Somali Republic, Djibouti, Kenya and Ethiopia. This however, caused tensions between Somali state and its neighbouring countries. The vision of greater Somalia encouraged Somalia to go to war with Ethiopia and bring back the Somali Speaking regions starting with Ogadenia which caused the disastrous 1977-8 war with Ethiopia. Unfortunately, the loss from the war with Ethiopia humiliated the Somali state and led huge strategic defeat.

The Somali state crises begun when president Abdirashid A. Sharmaake was assassinated on October 1969. Hence, this can be remembered as the first starting point towards failure of Somali state. The army intervened to rescue the state that is when Said Barre took power in bloodless coup on October 21 1969, many supported the military and welcomed the regime. The military regime promised changes and followed new path as former Somali state failed to fulfil its promises. However, Barre regime lacked the capacity to cope with the elite power sharing which was the reason previous state failed. Again, a group of prominent members of military tried a coup in 1971 but this one failed resulting the killing of coup plotters. The outcome of the persecution of the coup plotters marked the return of the clannish feelings. It was 23 January 1975 when 10 leading Islamic scholars and many more others were persecuted marking another turning point towards the collapse of the Somali state. After the fall of the central state in the country many attempts were made to make peace and bring warring parts on the negotiation table. After the Ethiopian intervention AMISOM came in 2007 in a support of the struggling Somali state. It was the African Union who gave hand to Somalia and supported peace keeping mission in the country with the help of the United Nations. AMISOM's peace-keeping mission encountered many challenges and faced numerous threats from Al-Shabaab a militia group that is against the Somali state. In general, the research discloses that AMISOM operation lacks appropriate human and logistic resources as well as the strategy to stabilize the country and get rid of the militia groups like Al-Shabaab. 


\section{References}

Abdullahi, 2017 - Abdullahi A. (2017). Making Sense of Somali History, London: Adonis\&Abbey Publishers Co.

Abdullahi, 2016 - Abdullahi A. (2016). Recovering the Somali State: Islam, Islamism and Traditional Justice, London: Adonis\&Abbey Publishers.

Abdurahman, 1992 - Abdurahman A. (1992). Trabalism, Nationalism and Islam: The Crisis of Political Loyolty in Somalia', Master's Thesis, McGill University.

Albin-Lackey, 2008 - Albin-Lackey C. (2008). So Much to Fear: War Crimes and the Devastation of Somalia, Human Rights Watch, 3.

Annan, 1997 - Annan K. (1997). Peace Operations and the UN", Paper delivered at Conflict Resolution Monitor 1, Centre for Conflict Resolution, Department of Peace Studies, University of Bradford, pp. 25-32.

Chirumamilla, 2011 - Chirumamilla S. (2011). U.S. intervention in the Horn: Revisiting Ethiopia Somalia dispute [Electronic resource]. URL: https://shodhganga.inflibnet.ac.in/bitstream/ 10603/1861/13/13_chapter6.pdf

Chonghaile, 2014 - Chonghaile C.N. (2014). Kenyan troops launch beach assault on Somali city of Kismayo. The Guardian.

Clarke, Gosende, 2000 - Clarke, W.S., Gosende R. (2000). Somalia: Can a Collapsed State Reconstitute itself? in Rotberg (ed.), State Failure and State Weakness in a Time of Terror, Washington: Brookings Institution Press.

De Waal, 1996 - De Waal A. (1996). Class and Power in a Stateless Somalia, A Discussion Paper, [Electronic resource]. URL: http://justiceafrica.org/wp-content/uploads/2016/o7/DeWaal_ ClassandPowerinSomalia.pdf

Elmi, 2010 - Elmi A.A. (2010). Understanding the Somalia Conflagration: Identity, Political Islam and Peacebuilding, Oxford: Pambazuka Press. Praeger.

Fishel, 1997 - Fishel, J.T. (1997). Civil Military Operations in the New World, Westport, CT:

Goldstone, 2014 - Goldstone J.A. (2014). Revolution: A Very Short Introduction, Oxford: Oxford University Press.

Heinlein, 2014 - Heinlein P. (2014). African Nations Back Kenyan Offensive in Somalia, Voice of America.

Klay, Kieh, 2002 - Klay G., Kieh Jr. (2002). Theories of Conflict and Conflict Resolution, in George Klay Kieh Jr and Ida Rousseau Mukenge (eds). Zones of Conflict in Africa: Theories and Cases. (Westport, Conn: Praeger), 3.

Lewis, 1993 - Lewis M. (1993). Understanding Somalia: Guide to Culture, History, and social Institutions, London: Haan Associates.

Lyons, Samatar, 1995 - Lyons T., Samatar A. (1995). Somalia: State Collapse, Multilateral intervention, and Strategies for Political Reconstruction, Washington: The Brookings Institution Occasional Paper.

MacQueen, 2002 - MacQueen N. (2002). United Nations Peacekeeping in Africa since 1960, London: Routledge.

Menkhaus, 1997 - Menkhaus K. (1997). US Foreign Assistance Somalia: Phoenix from the Ashes? Middle Eastern Policy, 1: 5 .

Menkhaus, Prendergast, 1995 - Menkhaus M., Prendergast J. (1995). Governance and Economic Survival in Post-intervention Somalia, CISIS Africa Note, No. 172. [Electronic resource]. URL: https://www.csis.org/analysis/africa-notes-governance-and-economic-survival-postintervention somalia-may-1995

Murithi, 2007 - Murithi T. (2007). Institutionalizing Pan-Africanism: Transforming the values and principles into policy and practice, Institute For Security Studies (143).

Nkaisserry, 1997 - Nkaisserry J.K. (1997). The Ogaden War: An Analysis of its Causes and its

Impact on Regional Peace and on the Horn of Africa. USAWC Strategic Research Project, US Army War College Carlisle Barracks, Pennsylvania.

World Bank, 2005 - World Bank (2005). Conflict in Somalia: Drivers and dynmics, New York: World Bank Publications. 